\title{
Ten Most Highly Cited Papers in Journal of Risk and Financial Management (JRFM), 2018-2020
}

\author{
Michael McAleer 1,2,3,4 (D) \\ 1 Department of Finance, Asia University, Taichung 41354, Taiwan; michael.mcaleer@gmail.com \\ 2 Discipline of Business Analytics, University of Sydney Business School, Darlington 2006, Australia \\ 3 Econometric Institute, Erasmus School of Economics, Erasmus University Rotterdam, \\ 3062 PA Rotterdam, The Netherlands \\ 4 Department of Economic Analysis and ICAE, Complutense University of Madrid, 28040 Madrid, Spain
}

Received: 13 November 2020; Accepted: 19 November 2020; Published: 25 November 2020

Of the numerous important, significant, and high-quality papers that have been published in the Journal of Risk and Financial Management (JRFM), the journal's highly dedicated and efficient team have determined the top 10 cited papers for 2018-2020, as listed in the references, two of which are included in the World Health World Health Organization's (2020a, 2020b) list of "WHO COVID-19 Global literature on coronavirus disease", and three of which are sole-authored papers.

The topics covered include Blockchain-Based ICOs: Pure Hype or the Dawn of a New Era of Startup Financing?; Long- and Short-Term Cryptocurrency Volatility Components: A GARCH-MIDAS Analysis; Intellectual Capital Performance and Profitability of Banks: Evidence from Pakistan; A Survey on Efficiency and Profitable Trading Opportunities in Cryptocurrency Markets; Spillover Risks on Cryptocurrency Markets: A Look from VAR-SVAR Granger Causality and Student's-t Copulas; Prevention Is Better Than the Cure: Risk Management of COVID-19; Exploratory Study Based on a Questionnaire Concerning Green and Sustainable Finance, Corporate Social Responsibility, and Performance: Evidence from the Romanian Business Environment; Risk Management of COVID-19 by Universities in China; Enterprise Risk Management Practices and Firm Performance; the Mediating Role of Competitive Advantage and the Moderating Role of Financial Literacy; and Suspending Classes Without Stopping Learning: China's Education Emergency Management Policy in the COVID-19 Outbreak.

The brief review of the ten papers is given in alphabetical order. The numbers of abstract views, full-text views, citations, and altmetric scores can easily be seen by clicking on the website for each paper.

Ante et al. (2018) [3269 abstract views, 3627 full-text views] explore the determinants of initial coin offering (ICO) success, where success is defined as the amount of capital a project could raise. ICOs are a tool for startups in the blockchain ecosystem to raise early capital with relative ease. The market for ICOs has grown at a rapid pace since its start in 2013. The authors analyze a unique dataset of 278 projects that finished their ICOs by August 2017 to assess the determinants of funding success that are derived from the crowdfunding and venture capital literature. The results show that ICOs exhibit similarities to classical crowdfunding and venture capital markets. Specifically, the authors identify resemblances in determinants of funding success regarding human capital characteristics, business model quality, project elaboration, and social media activity.

Conrad et al. (2018) [5860 abstract views, 5662 full-text views] use the GARCH-MIDAS model to extract the long- and short-term volatility components of cryptocurrencies. As potential drivers of Bitcoin volatility, the authors consider measures of volatility and risk in the US stock market, as well as a measure of global economic activity. They find that S\&P 500 realized volatility has a negative and highly significant effect on long-term Bitcoin volatility. The finding is atypical for volatility 
co-movements across financial markets. Moreover, the authors find that the S\&P 500 volatility risk premium has a significantly positive effect on long-term Bitcoin volatility. Finally, they find a strong positive association between the Baltic dry index and long-term Bitcoin volatility. This result shows that Bitcoin volatility is closely linked to global economic activity. Overall, the findings can be used to construct improved forecasts of long-term Bitcoin volatility.

Haris et al. (2019) [2309 abstract views, 2455 full-text views] contribute to the existing literature on intellectual capital (IC) performance and profitability by extending evidence from Pakistan. The authors examine the impact of IC performance on the profitability of Pakistan financial institutions, and how corporate governance, bank-specific, industry-specific, and country-specific indicators effect Pakistan bank profitability. The results report both the linear and non-linear impact of IC performance on profitability, which affirms an inverted U-shaped relationship. Among the three value-added intellectual coefficient (VAIC) components, capital employed efficiency (CEE), and human capital efficiency (HCE) are found to have a significantly positive effect, and structural capital efficiency (SCE) is found to have a significantly negative impact on bank profitability. The authors note a positive impact on the profitability of factors like board independence, director compensation, and higher capitalization. They report a negative impact on the profitability of factors such as board size, board meetings, credit risk, industry concentration, and economic growth. The results also indicate low profitability of banks during the period of government transition. The authors provide insights into the important profitability drives and suggest that the impact of investment in IC on profitability is limited to an extent. The findings are likely to be useful for policy makers, management, and academics.

Kyriazis (2019) [2508 abstract views, 4733 full-text views] conducts a systematic survey on whether the pricing behavior of cryptocurrencies is predictable. The efficient market hypothesis is rejected and speculation is feasible via trading. The author centers interest on the rescaled range (R/S) and detrended fluctuation analysis (DFA), as well as other relevant methodologies of testing long memory in returns and volatility. The author finds that the majority of academic papers provide evidence for the inefficiency of Bitcoin and other digital currencies of primary importance. Nevertheless, large steps towards efficiency in cryptocurrencies have been traced in recent years, which can lead to less profitable trading strategies for speculators.

Luu Duc Luu Duc Huynh (2019) [2548 abstract views, 3407 full-text views] contributes quantitative evidence to the embryonic literature, as well as existing empirical evidence regarding spillover risks among cryptocurrency markets. By using vector autoregressive model (VAR)-structural vector autoregressive model (SVAR) Granger causality and Student's t copulas, the author finds that Ethereum is likely to be the independent coin in this market, while Bitcoin tends to be the spillover effect recipient. The author sheds further light on investigating the contagion risks among cryptocurrencies by using Student's t copulas for joint distribution. This result suggests that all coins negatively change in terms of extreme value. Investors are advised to pay greater attention to "bad news" and moving patterns in order to make timely decisions on three types (namely, buy, hold, and sell).

In a current year paper, McAleer (2020) [10,393 abstract views, 6484 full-text views] discusses a novel coronavirus that was reported to the World Health Organization (WHO) in China on 31 December 2019. The WHO named the disease COVID-19 on 11 February 2020. As of 26 February 2020, the disease has been detected on all continents, except for Antarctica. Daily updates on COVID-19 since early February 2020 have made headline news worldwide for much of 2020. The author evaluates risk management based on the Global Health Security (GHS) Index of global health security capabilities in 195 countries. The GHS Index lists the countries best prepared for an epidemic or pandemic. COVID-19 is compared with two related coronavirus epidemics, SARS and MERS, in terms of the number of reported human infections, deaths, countries, major country clusters, timelines, and the likelihood of discovering a safe, effective, and approved vaccine.

Popescu and Popescu (2019) [1948 abstract views, 2955 full-text views] argue that green and sustainable finance, corporate social responsibility, and financial and non-financial performance are attracting widespread interest due to the challenging times that the business environment is currently 
facing. Moreover, green and sustainable finance, corporate social responsibility, and intellectual and human capital have become central issues in measuring organizational success, competitive advantage, and influence on the marketplace. The authors address the relationship between corporate social responsibility, intellectual capital, and performance, providing insights and evidence from a Romanian business environment. The questionnaire method was used for the targeted research objectives, which referred to: (a) Romanian organizations and local community understanding of green and sustainable finance, corporate social responsibility, and intellectual capital; (b) corporate social responsibility actions taken by Romanian organizations and the local community; (c) main drivers of corporate social responsibility and intellectual capital in Romanian organizations; and (d) ways to enhance financial and non-financial performance of Romanian organizations with the aid of corporate social responsibility and intellectual capital. The findings support a strong relationship between corporate social responsibility, intellectual capital, and performance in the Romanian business environment. The authors show that Romanian entities operate on a socially responsible level, being aware of the importance and the advantages brought by both corporate social responsibility and intellectual capital when it comes to enhancing profit, productivity, and performance.

In another current year paper, Wang et al. (2020) [16,899 abstract views, 13,633 full-text views] discuss the rapid spread of new coronaviruses throughout China and the world in 2019-2020 that has had a great impact on China's economic and social development. As the backbone of Chinese society, Chinese universities have made significant contributions to emergency risk management. Such contributions have been made primarily in the following areas: alumni resource collection, medical rescue and emergency management, mental health maintenance, control of staff mobility, and innovation in online education models. Through the support of these methods, Chinese universities have played a positive role in the prevention and control of the epidemic situation. However, they also face the problems of alumni's economic development difficulties, the risk of deadly infection to medical rescue teams and health workers, infection of teachers and students, and the unsatisfactory application of information technology in resolving the crisis. In response to these risks and emergency problems, the authors propose some corresponding solutions for public dissemination, including issues related to medical security, emergency research, professional assistance, positive communication, and hierarchical information-based teaching.

Yang et al. (2018) [3871 abstract views, 13,562 full-text views] argue that, in the current turbulent market, firms spend substantial tangible and intangible resources to gain competitive advantage and superior performance. Prior studies have discussed several determinants of competitive advantage and performance, particularly in developed economies, whereas small- and medium-sized enterprises (SMEs) in emerging economies have received minor attention. The authors examine the mediating role of competitive advantage between enterprise risk management practices and SME performance, and the moderating role of financial literacy between enterprise risk management practices and competitive advantage. A structured questionnaire is used to collect data from 304 SMEs operating in the emerging market of Pakistan. The hypotheses are tested through structural equation modeling (SEM) in an analysis of moment structures (AMOS). The results indicate that enterprise risk management practices significantly influence competitive advantage and SME performance. Competitive advantage partially mediates the relationship between enterprise risk management practices and SME performance. Additionally, financial literacy significantly moderates the relationship between enterprise risk management practices and competitive advantage. Firms are advised to implement formal enterprise risk management practices to gain competitive advantage and superior performance. Top managers need to have enough financial education so that they will be able to perform risk management practices in an efficient way to gain a competitive position in the market.

In the final paper, which is also in the current year, Zhang et al. (2020) [11,590 abstract views, 11,187 full-text views] discuss, against the backdrop of the COVID-19 outbreak, an emergency policy initiative called "Suspending Classes Without Stopping Learning", that was launched by the Chinese government to continue teaching activities as schools across the country were closed 
to contain the virus. However, there is ambiguity and disagreement about what to teach, how to teach, the workload of teachers and students, the teaching environment, and the implications for education equity. Possible difficulties that the policy faces include: the weakness of the online teaching infrastructure, the inexperience of teachers (including unequal learning outcomes caused by teachers' varied experience), the information gap, and the complex environment at home, among others. In order to tackle the problems, the authors suggest that the government needs to promote the construction of an educational information superhighway, consider equipping teachers and students with standardized home-based teaching/learning equipment, conduct online teacher training, include the development of massive online education in the national strategic plan, and support academic research into online education, especially education to help students with online learning difficulties.

Funding: This research received no external funding.

Acknowledgments: The author wishes to thank Kaia Lv for efficient contributions to the journal platform, and for providing the data and information. For financial support, the author acknowledges the Australian Research Council and the Ministry of Science and Technology (MOST), Taiwan.

Conflicts of Interest: The author declares no conflict of interest.

\section{References}

Ante, Lennart, Philipp Sandner, and Ingo Fiedler. 2018. Blockchain-Based ICOs: Pure Hype or the Dawn of a New Era of Startup Financing? Journal of Risk and Financial Management 11: 80. [CrossRef]

Conrad, Christian, Anessa Custovic, and Eric Ghysels. 2018. Long- and Short-Term Cryptocurrency Volatility Components: A GARCH-MIDAS Analysis. Journal of Risk and Financial Management 11: 23. [CrossRef]

Haris, Muhammad, HongXing Yao, Gulzara Tariq, Ali Malik, and Hafiz Mustansar Javaid. 2019. Intellectual Capital Performance and Profitability of Banks: Evidence from Pakistan. Journal of Risk and Financial Management 12: 56. [CrossRef]

Kyriazis, Nikolaos A. 2019. A Survey on Efficiency and Profitable Trading Opportunities in Cryptocurrency Markets. Journal of Risk and Financial Management 12: 67. [CrossRef]

Luu Duc Huynh, Toan. 2019. Spillover Risks on Cryptocurrency Markets: A Look from VAR-SVAR Granger Causality and Student's-t Copulas. Journal of Risk and Financial Management 12: 52.

McAleer, Michael. 2020. Prevention Is Better Than the Cure: Risk Management of COVID-19. Journal of Risk and Financial Management 13: 46. [CrossRef]

Popescu, Cristina Raluca Gh., and Gheorghe N. Popescu. 2019. An Exploratory Study Based on a Questionnaire Concerning Green and Sustainable Finance, Corporate Social Responsibility, and Performance: Evidence from the Romanian Business Environment. Journal of Risk and Financial Management 12: 162. [CrossRef]

Wang, Chuanyi, Zhe Cheng, Xiao-Guang Yue, and Michael McAleer. 2020. Risk Management of COVID-19 by Universities in China. Journal of Risk and Financial Management 13: 36. [CrossRef]

World Health Organization. 2020a. WHO COVID-19 Global Literature on Coronavirus Disease. Available online: https:/www.who.int/emergencies/diseases/novel-coronavirus-2019/global-research-onnovel-coronavirus-2019-ncov (accessed on 24 August 2020).

World Health organization (WHO). 2020b. Coronavirus Disease (COVID-19) Pandemic. Available online: https://www.who.int/emergencies/diseases/novel-coronavirus-2019 (accessed on 11 November 2020).

Yang, Songling, Muhammad Ishtiaq, and Muhammad Anwar. 2018. Enterprise Risk Management Practices and Firm Performance, the Mediating Role of Competitive Advantage and the Moderating Role of Financial Literacy. Journal of Risk and Financial Management 11: 35. 
Zhang, Wunong, Yuxin Wang, Lili Yang, and Chuanyi Wang. 2020. Suspending Classes without Stopping Learning: China's Education Emergency Management Policy in the COVID-19 Outbreak. Journal of Risk and Financial Management 13: 55. [CrossRef]

Publisher's Note: MDPI stays neutral with regard to jurisdictional claims in published maps and institutional affiliations.

(C) 2020 by the author. Licensee MDPI, Basel, Switzerland. This article is an open access article distributed under the terms and conditions of the Creative Commons Attribution (CC BY) license (http://creativecommons.org/licenses/by/4.0/). 